\title{
Sorption of chromium (VI) by spent grain under batch conditions
}

\begin{abstract}
Batch experiments were performed to evaluate the ability of spent grain to remove chromium (VI) from aqueous solution. Parameters investigated include $\mathrm{pH}$, contact time, sorbent dosage, agitation rate, and the presence of other anions. Application of the Langmuir isotherm to the $\mathrm{Cr}(\mathrm{VI})$ ï spent grain system provided a maximum sorption capacity of 18.94 $\mathrm{mg} / \mathrm{g}$. This value compares favorably with other reported values for low-cost materials. Anions such as phosphate, arsenate, nitrate, and sulfate were antagonistic toward the uptake of $\mathrm{Cr}(\mathrm{VI})$ by spent grain. It was successful in removing $\mathrm{Cr}(\mathrm{VI})$ from a sample of electroplating waste.
\end{abstract}

Keyword: Low-cost material; Spent grain; Sorption; Chromium 